\title{
Influence of urea-fortified corncob diets on growth performance and carcass characteristics in West African dwarf goats
}

\author{
Kolo, U. M ${ }^{1 *}$., Adeloye, A. $\mathrm{A}^{2}$ and Yousuf, M. B ${ }^{2}$ \\ ${ }^{1}$ Department of Animal Science, University of Maiduguri, P.M.B 1069, Maiduguri, Nigeria \\ (*uskolo220@gmail.com). \\ ${ }^{2}$ Department of Animal production, University of Ilorin, Ilorin, Nigeria.
}

\begin{abstract}
The experiment was carried out to determine the effect of urea-fortified concentrate corncob diets on growth performance and carcass characteristics of West African dwarf (WAD) goats. Fifteen WAD goats with an average weight of $9.33 \mathrm{~kg}$ were studied. The animals were weighted and randomly assigned to five (5) treatments in a completely randomized design (CRD). The treatments were of different levels i.e. $0 \%, 1 \%, 2 \%, 3 \%$ and $4 \%$ of urea in corncob-based concentrate diets. Results showed variation $(\mathrm{P}<0.05)$ in the live weight among all the treatments while no effect was observed in average daily weight gain, average daily feed intake and feed conversion ratio, carcass and non-carcass characteristics among the treatment groups. However, the physicochemical properties of the meat showed that meat water holding capacity, moisture, dry matter, crude fibre and ash were not influenced by urea but there was a significant $(\mathrm{P}<0.05)$ difference in meat $\mathrm{pH}$ and meat crude protein among the treated groups. In conclusion, for better performance in the live weight gain of WAD goats, $3 \%$ best level inclusion of urea fortified corncob diet should be taken into cognizance.
\end{abstract}

Keywords: Carcass characteristics; Corncob; Urea; West African Dwarf Goats; Nigeria.

\section{INTRODUCTION}

In the developing countries, small ruminants play an important role in the livelihood of small scale farmers as a major component of livestock mixed farming system. Domesticated small ruminants-sheep and goats- provide meat, milk, skin, fiber, and manure to large number of low income, marginal farmers and landless laborers (Acharya et al., 2011).

Among the complex interacting factors that affect livestock production, nutrition is one of the most important. Poor nutrition is one of the main constraints of livestock productivity in SubSaharan Africa as feed resources are limited in quantity and quality (Nsahlai et al., 1998). Recent trends in animal nutrition in Nigeria based on the principle of minimum input indicate focus of attention on the utilization of non-conventional sources of feed such as agricultural by products for ruminant feeding (Fasae et al., 2007). This will reduce the cost of animal production without decrease in productivity (Odeyinka, 2001). Crop residues are the most abundant and readily available feed resources for livestock production (Belete, 2006). However, crop residues 
especially cereal by-products are characterized by low nutrient content and digestibility as well as poor voluptuary consumption by ruminant animals (Preston and Leng, 1987). This is a basic limitation in residues such as corncob with low crude protein, fermentable energy and mineral contents. Improved utilization of corncob can be achieved through appropriate supplementation, chemical treatment or both, in order to facilitate the microbial breakdown of the cell wall.

However, cotton seed cake used as a protein supplement has relatively low rumen degradability and is, therefore, a good source of by-pass protein (FAO, 1993). Urea is a simple compound that contains $46.7 \%$ of nitrogen compared to $16 \%$ for most proteins. Urea treatment emerged as the method of choice for use at farm level in the tropics as it is best adapted to the conditions of smallholder farmers (Chenost, 1995). The major advantages of using urea for crop residue improvement are the ease of handling, access and transportation. Urea does not pose a major risk during handling and using it (Sundstol and Coxworth, 1984). This paper presents, the results of a study designed to assess the performance and carcass characteristics of dwarf goats fed ureafortified concentrate corncob diets.

\section{MATERIALS AND METHODS}

\subsection{Experimental Site}

The study was conducted at small ruminant unit of the Teaching and Research Farm, University of Ilorin, Ilorin $\left(82^{0} 9^{\prime} \mathrm{N}, 43^{0} 5^{\prime} \mathrm{E}\right)$ located at an elevation of $305 \mathrm{~m}$ above the sea level in the North central Zone of Nigeria . The average annual rainfall of the area is about $1234.4 \mathrm{~mm}$ while the mean annual ambient temperature is around $27{ }^{0} \mathrm{C}$. Relative humidity is higher during the rainy season (Olofintoye and Salami, 2011).

\subsection{Experimental Feeds}

Diets were formulated using corn cob, cotton seed cake, mineral/vitamin, salt and urea. Corncob was collected from Teaching and Researcher Farm, University of Ilorin. After harvesting and processing, the corncob was sun-dried and milled into small particle suitable for mixing with other feed ingredients. The experimental diet compositions are shown in table 1.

\subsection{Experimental Animals, Feeding and Management}

Fifteen growing WAD goats, with an average weight of $9.33 \mathrm{~kg}$ were used for the study. The animals were given prophylaxis against internal and external parasites and were allotted to the 
five dietary treatments $T_{0}, T_{1}, T_{2}, T_{3}$ and $T_{4}$ in a completely randomized manner with three animals per treatment. Feed consumption from each treatment was measured on daily basis by subtracting left over from feed served per goat. Adequate measures were taken to safeguard against spillage and related wastage. The experiment period lasted for 70 days, the goats, with average age of 3 months and male, the urea were include different levels (\%, 0, 1, 2, 3 and 4) for treatment 1-4 respectively to diets.An experiment feed was given through adaptation period. Animals were fed for seven days as an adaptation period before the measurements were commenced. Experimental diets were fed to the animals once daily by $8.00 \mathrm{am}$ at the rate of $5 \%$ (DM basis) of their body weight with free access to water (ad libitum).

Table 1. The feed constituents and proximate Composition of Experimental Diets (\%).

\begin{tabular}{|llllll|}
\hline \multicolumn{7}{c}{ Treatments } & with \% urea inclusion & & \\
\hline Ingredients (\%) & 0 & 1 & 2 & 3 & 4 \\
\hline Corn cob & 51.5 & 51.5 & 51.5 & 51.5 & 51.5 \\
\hline Cotton seed cake & 46.5 & 45.5 & 44.5 & 43.5 & 42.5 \\
\hline Minerals/Vitamins & 1.00 & 1.00 & 1.00 & 1.00 & 1.00 \\
\hline Salt & 1.00 & 1.00 & 1.00 & 1.00 & 1.00 \\
\hline Urea & 0.00 & 1.00 & 2.00 & 3.00 & 4.00 \\
\hline Total & 100 & 100 & 100 & 100 & 100 \\
\hline
\end{tabular}

\subsection{Slaughter Technique}

At the end of the feeding trial, two goats were kept without feed for 14-16 hours. The moslem method of slaughter were adapted. The goats had access water. Pre-slaughter weight of the animals was taken (Kadim et al., 2003). Weights of head with tongues, feet, skin, blood, liver, heart, kidney with fat, lung and trachea and full and empty gastro-intestinal tracts were recorded. The empty body weight (EBW) was calculated as slaughter body weight minus gastro-intestinal tract and contents from the slaughter weight. The hot carcass weight (HCW) was determined after removing the skin, head, forefeet, hind feet and all the viscera and fat depots (kidney and gut fat). Dressing percentage (DP) was calculated as percentage of hot carcass weight to slaughter body weight or empty body weight. Meat samples collected from thigh (longissimusdorsi) muscle, were analyzed for proximate composition. Rumen $\mathrm{pH}$ and meat $\mathrm{pH}$ were obtained immediately after slaughter using a portable digital $\mathrm{pH}$ meter as described by Davilla et al. (2013). 


\subsection{Chemical and Statistical Analyses}

Samples of the experimental diets and meat were analyzed for proximate composition using the procedures ofAssociation of Official Analytical Chemist AOAC (2002). Data from the carcass, non-carcass characteristics and physiochemical properties of the meat were subjected to one way analysis of variance (ANOVA). Significant differences between treatment means were assessed using the Duncan's Multiple Range Test (Steel and Torrie, 1980).

\section{RESULTS}

\subsection{Growth Performance}

The results on growth performance are presented in table 2. The mean daily feed intake ranged from 320.16 to $390.21 \mathrm{~g}$. There was nosignificant difference among treatments $(\mathrm{P}>0.05)$. The highest mean daily feed intake was recorded among goats fed on the control diet. The final live weight, there was a significant difference among the treatments $(\mathrm{P}<0.05)$ at the end of experiment.

Table 2. Growth Performance of WAD goats fed urea-fortified concentrate corncob diets.

\begin{tabular}{|lllllll|}
\hline & \multicolumn{6}{c}{ \% Urea inclusion } \\
\cline { 2 - 7 } Treatments & $\mathbf{0}$ & $\mathbf{1}$ & $\mathbf{2}$ & $\mathbf{3}$ & $\mathbf{4}$ & \\
\hline Initial live weight $(\mathrm{kg})$ & 9.17 & 9.00 & 9.33 & 10.17 & 9.00 & $0.32^{\mathrm{NS}}$ \\
\hline Mean daily feed intake $(\mathrm{g})$ & 390.21 & 359.31 & 342.59 & 376.72 & 320.16 & $11.52^{\mathrm{NS}}$ \\
\hline Final live weight $(\mathrm{kg})$ & $9.33^{\mathrm{ab}}$ & $7.67^{\mathrm{ab}}$ & $8.00^{\mathrm{ab}}$ & $11.83^{\mathrm{a}}$ & $6.50^{\mathrm{b}}$ & $0.69^{*}$ \\
\hline
\end{tabular}

Note: $\mathrm{ab}=$ Means on the same row with different superscripts differ significantly $(\mathrm{P}<0.05)$.

$\mathrm{SEM}=$ Standard error of mean; NS=Not significant $(\mathrm{P}>0.05) ; *=$ Significant $(\mathrm{P}<0.05)$.

\subsection{Carcass and Non-Carcass Characteristics}

The carcass yield of West African dwarf goats fed with concentrate corncob diets (Table 3). There were no significant $(\mathrm{P}>0.05)$ differences in terms of the hot carcass weight, emptied body weight, dressing percentage and weight of organs among treatment groups that fed graded levels of urea fortified concentrate corncob diet. The dressing percentage values among the treatment groups fed concentrate corncob do not differ significantly $(\mathrm{P}>0.05)$. The values of the dressing percentage ranged from 41.665 to $45.280 \%$.

The weights of the heart, lungs, liver, kidney, spleen, abdominal fat, blood and gastrointestinal tract of corncob diet -fed WAD goats are not significantly influenced as indicated in table 3 . The 
results obtained for the weight of skin and legs were found to be similar among different groups that fed different levels urea with concentrate mixed corncob diet. The absolute weight of head was significantly $(\mathrm{P}<0.05)$ different.

Table 3. Weights and proportion of carcass and Non-carcass characteristics of WestAfrican dwarf goats fed urea-fortified concentrate corncob diets.

\begin{tabular}{|c|c|c|c|c|c|c|}
\hline \multirow[t]{2}{*}{ Parameters } & \multicolumn{5}{|c|}{ \% Urea inclusion } & \multirow[t]{2}{*}{ S.E.M } \\
\hline & $\boldsymbol{0}$ & 1 & 2 & 3 & 4 & \\
\hline \multicolumn{7}{|l|}{ Carcass component } \\
\hline Live weight at slaughter $(\mathrm{kg})$ & 10.00 & 7.50 & 8.00 & 10.50 & 5.75 & $0.83^{\mathrm{NS}}$ \\
\hline Slaughter weight $(\mathrm{kg})$ & 9.00 & 6.50 & 6.50 & 8.75 & 5.25 & $0.72^{\mathrm{NS}}$ \\
\hline Hot carcass weight $(\mathrm{kg})$ & 3.75 & 3.00 & 2.90 & 3.96 & 2.15 & $0.32^{\mathrm{NS}}$ \\
\hline Empty body weight $(\mathrm{kg})$ & 5.45 & 4.25 & 4.00 & 4.68 & 3.40 & $0.38^{\mathrm{NS}}$ \\
\hline Carcass length (inches) & 21.50 & 18.50 & 19.25 & 19.25 & 19.50 & $0.64^{\mathrm{NS}}$ \\
\hline Dressing (\%) & 41.67 & 44.85 & 44.57 & 45.28 & 41.39 & $1.68^{\mathrm{NS}}$ \\
\hline \multicolumn{7}{|l|}{ Absolute weight } \\
\hline Heart $(\mathrm{g})$ & 47.50 & 37.00 & 34.50 & 49.50 & 41.00 & $2.55^{\mathrm{NS}}$ \\
\hline Lungs and trachea $(\mathrm{g})$ & 202.50 & 199.50 & 201.00 & 207.00 & 197.50 & $1.54^{\mathrm{NS}}$ \\
\hline Liver $(\mathrm{g})$ & 223.0 & 218.5 & 221.0 & 226.5 & 216.0 & $1.55^{\mathrm{NS}}$ \\
\hline Kidney (g) & 38.0 & 32.0 & 35.0 & 37.0 & 29.5 & $1.54^{\mathrm{NS}}$ \\
\hline Blood $(\mathrm{kg})$ & 1.00 & 1.00 & 1.50 & 1.75 & 0.50 & $0.17^{\mathrm{NS}}$ \\
\hline Full G.I.T (kg) & 3.55 & 2.25 & 2.50 & 4.18 & 1.85 & $0.44^{\mathrm{NS}}$ \\
\hline \multicolumn{7}{|l|}{ Offals } \\
\hline Head $(\mathrm{kg})$ & 0.80 & 0.55 & 0.63 & 0.80 & 0.55 & $0.06^{\mathrm{NS}}$ \\
\hline Legs (kg) & 0.30 & 0.23 & 0.20 & 0.35 & 0.33 & $0.03^{\mathrm{NS}}$ \\
\hline Skin (kg) & 0.85 & 0.43 & 0.58 & 0.65 & 0.40 & $0.07^{\mathrm{NS}}$ \\
\hline \multicolumn{7}{|l|}{ Proportions on slaughter weight } \\
\hline Blood (\%) & 11.11 & 14.55 & 14.38 & 21.20 & 9.72 & $1.74^{\mathrm{NS}}$ \\
\hline Head (\%) & $8.89^{\mathrm{a}}$ & $8.30^{\mathrm{ab}}$ & $3.40^{\mathrm{c}}$ & $4.24^{\mathrm{c}}$ & $5.78^{\mathrm{bc}}$ & $0.76^{*}$ \\
\hline Skin $(\%)$ & 9.00 & 6.28 & 9.12 & 7.65 & 7.23 & $0.50^{\mathrm{NS}}$ \\
\hline $\operatorname{Leg}(\%)$ & 3.34 & 3.36 & 3.40 & 4.24 & 5.78 & $0.39^{\mathrm{NS}}$ \\
\hline G.I.T (\%) & 39.45 & 36.06 & 37.23 & 45.67 & 35.00 & $2.39^{\mathrm{NS}}$ \\
\hline Heart (\%) & 0.53 & 0.57 & 0.58 & 0.59 & 0.79 & $0.04^{\mathrm{NS}}$ \\
\hline Lung (\%) & 2.25 & 3.14 & 3.40 & 2.60 & 3.84 & $0.29^{\mathrm{NS}}$ \\
\hline Liver $(\%)$ & 2.48 & 3.39 & 3.75 & 2.85 & 4.20 & $0.32^{\mathrm{NS}}$ \\
\hline Kidney (\%) & 0.42 & 0.50 & 0.59 & 0.45 & 0.57 & $0.03^{\mathrm{NS}}$ \\
\hline
\end{tabular}

Note: abc $=$ Means on the same row with different superscripts differ significantly $(\mathrm{P}<0.05)$; $\mathrm{SEM}=$ Standard error of mean; NS= Not significant $(\mathrm{P}>0.05)$; * Significant $(\mathrm{P}<0.05)$.

\subsection{Meat Physicochemical Properties}

The physicochemical properties of the West African dwarf goats fed with concentrate mixed corncob (urea treated) dietsare shown in table 4. The results show that the rumen $\mathrm{pH}$ and water (C) CNCS, Mekelle University 
holding capacity of the goats fed on concentrate mixed and urea treated corncob diets did not differ significantly $(\mathrm{P}>0.05)$ but significant difference $(P<0.05)$ is observed for meat $\mathrm{pH}$ among the treatment groups. The meat $\mathrm{pH}$ and water holding capacity ranged from 5.90 to 6.45 and 0.740 to 0.890 respectively. The results of proximate composition of the meat sample showed crude protein and crude fat were differed significantly $(P<0.05)$ among the dietary treatments while moisture content, crude fibre and ash were not significantly different $(\mathrm{P}>0.05)$. The results of dry matter, moisture content, crude protein, crude fat, crude fibre and ash content of the muscle ranged from 21.01 to $23.67,76.33$ to $78.99,62.010$ to $68.135,10.180$ to $14.850,1.805$ to 1.930 and 3.670 to $5.045 \%$ respectively.

Table 4. Meat Physiochemical properties of West African dwarf goats fed urea-fortified concentrate corncob diets.

\begin{tabular}{|lllllll|}
\hline Parameter & \multicolumn{7}{c}{ \% Urea inclusion } & \multirow{2}{*}{ S.E.M } \\
\cline { 2 - 6 } & $\mathbf{0}$ & $\mathbf{1}$ & $\mathbf{2}$ & $\mathbf{3}$ & $\mathbf{4}$ & \\
\hline Physicochemical properties & & & & & & \\
\hline Meat pH & $6.20^{\mathrm{ab}}$ & $6.45^{\mathrm{b}}$ & $6.15^{\mathrm{ab}}$ & $6.40^{\mathrm{ab}}$ & $5.90^{\mathrm{a}}$ & $0.08^{*}$ \\
\hline Rumen pH & 6.80 & 6.20 & 6.60 & 6.25 & 6.05 & $0.13^{\mathrm{NS}}$ \\
\hline Water holding capacity & 0.74 & 0.83 & 0.89 & 0.82 & 0.76 & $0.04^{\mathrm{NS}}$ \\
\hline Composition & & & & & & \\
\hline Dry matter (\%) & 23.57 & 21.01 & 23.67 & 22.16 & 21.70 & $0.53^{\mathrm{NS}}$ \\
\hline Moisture content (\%) & 76.43 & 78.99 & 76.33 & 77.85 & 78.30 & $0.53^{\mathrm{NS}}$ \\
\hline (\% of DM) & & & & & & \\
\hline Crude protein (\%) & $62.01^{\mathrm{b}}$ & $64.50^{\mathrm{ab}}$ & $63.87^{\mathrm{ab}}$ & $63.11^{\mathrm{ab}}$ & $68.14^{\mathrm{a}}$ & $0.85^{*}$ \\
\hline Crude fat (\%) & $13.510^{\mathrm{ab}}$ & $10.180^{\mathrm{b}}$ & $14.850^{\mathrm{a}}$ & $11.340^{\mathrm{b}}$ & $11.060^{\mathrm{b}}$ & $0.65^{*}$ \\
\hline Crude fibre (\%) & 1.86 & 1.93 & 1.81 & 1.91 & 1.91 & $0.021^{\mathrm{NS}}$ \\
\hline Ash (\%) & 3.91 & 5.05 & 4.18 & 3.67 & 4.78 & $0.27^{\mathrm{NS}}$ \\
\hline
\end{tabular}

Note: $\mathrm{ab}=\mathrm{Means}$ on the same row with different superscripts differ significantly $(\mathrm{P}<0.05) ; \mathrm{SEM}=$ Standard error of mean; NS=Not significant $(\mathrm{P}>0.05) ; *=$ Significant $(\mathrm{P}<0.05)$; DM= Dry matter.

\section{DISCUSSION}

\subsection{Growth Performance}

The high mean daily feed intake in the urea-free diet is in contrast to what was reported by McDonald (1994); and Schneider et al. (1995) who reported that increase in level of crude protein in the diet would increase intake and delignification of lignocelluloses complex of corncobs by urea treatment. Fajemisin et al. (2012) applied that low dietary fibre fractions and 
adequate protein content in livestock diets enhanced nutrients intake.The highest mean daily live weight gain recorded in goats fed on the 3\% inclusion of urea could be attributed to the level of urea in the diet. Yilkal and Negassie (2015) reported that the amount of urea included in concentrate mixtures for ruminant should not exceed 3\%. The supplementation of urea treated rice straw with $1.3 \pm 0.5 \mathrm{~kg}$ cotton seed cake was reported to have a high improvement in feed efficiency by lowering the total feed dry matter requirement from $20 \mathrm{~kg} / \mathrm{kg}$ of live weight gain down to $10 \mathrm{~kg}$ (Dolberg and Finlayson, 1995). The final live weight of goats fed diet $3 \%$ urea was highest and could probably be due to the presence of urea treatment in the diet. Oosting (1993); and Van Soest (1994) observed swelling of cell walls which allowed greater diffusion of cellulolytic enzymes, disruption of bonds between lignin and cell wall carbohydrates, increased availability of the carbohydrate for degradation by rumen microorganisms and solubilisation of some of hemicellulose and crude protein in urea treated diets.

\subsection{Carcass and Non-Carcass Characteristics}

The dressing percentage values were within the range of $45-52 \%$ as for WAD goats below the range of 50.4-52.6\% (Ahamefule et al., 2000, 2005). Hassan and Idriss (2002) reported that 50\% is normal as dressing percentage of West African dwarf goats. According to Dhangar et al. (1992) the dressing percentage of animals depends on the level of nutrition, species, breed, sex, season, age, castration and live weight. It may also be influenced by the amount of gut fill at slaughter, whether the carcass is weighed hot or cold and by the number of body components included in the yield calculation. Therefore, when comparisons are made between animals using dressing percentages, aforesaid factors are important to consider. Payne and Wilson (1999) recorded an increase in dressing percentage with increasing proportions of concentrates in a ration. Thus, a high percentage of crude fibre and roughage with low digestibility may contribute to a low dressing percentage. Dhangar et al. (1992) reported that the dressing percentage on slaughter weight basis varied from $38.6 \%$ in small sized goats (black Bengal) to $49.7 \%$ in large sized goats (Beetal).

Results of the present study are in accordance with the findings of Dien et al. (1990) who observed no significant $(\mathrm{P}>0.05)$ difference in weight of visceral organs. Vidya et al. (2012) also reported non-significant $(\mathrm{P}>0.05)$ difference in the weight of pluck, liver, heart, testes, GIT, spleen, lungs with trachea of small ruminants. 


\subsection{Meat Physicochemical Properties}

The meat $\mathrm{pH}$ in this study ranged from 5.90 to 6.45. If glycogen declines pre-slaughter, $\mathrm{pH}$ decreases. It cannot increase. Of course, Lactate is the main product while comparisons reported by Varnam and Sutherland (1995) showed that a $\mathrm{pH}$ of 5.5 is desirable and is associated with light colored palatable meat. However, if pre-mortem glycogen reserves are low $(<0.65$ to $0.70 \%$ ), the result is a high $\mathrm{pH}$ meat, which at extreme levels, can cause an aesthetically unpleasant phenomenon of dark, firm and dry meat (Brown et al., 1990). Such meat is dark in color, tough, has a high water holding capacity and is prone to bacterial spoilage. The $\mathrm{pH}$ of the meat declines too quickly after slaughter and a pale, soft, exudative condition may develop. The results obtained in this study showed that moisture content was similar with reports by Gopalanet al. (1980) with an average meat moisture content of $74.2 \%$ while protein $(21.4 \%)$ and fat $(3.6 \%)$ were relatively low because they were expressed on dry matter basis.

\section{CONCLUSION}

The utilization of the urea treated crop residues has no deleterious effects on the growth performance,carcass and non-carcass characteristics, meat physicochemical properties of the WAD goats. It is therefore, recommended to use goat producers as dry season feedstuffs. It is further recommended that $3 \%$ level of inclusion of urea fortified corncob diet could be fed and will give better growth performance in WAD goats

\section{ACKNOWLEDGEMNENTS}

Authors thank all Staff of Department of Animal Science, University of Maiduguri and University of Ilorin, Nigeria. Mr. A B Amin for kind assistance.

\section{REFERENCE}

Acharya, S. N., Iwaasa, A. D., McAllister, T. A., Wang, Y \& Thomas, J. 2011. Animal performance and incidence of bloat in mixed Affalfa/sanifoin grazing. Plant Canada, Saint Mary’s University, Halifax, NS, Canada, July, 17-21, 2011.

Ahamefule, F. O., Ibeawuchi, J. A \& Ahunam, U. C. 2000. Intake, digestibility and nitrogen balance studies inWAD goats fed cassava peel-leaf meals. Proceeding of the society of 
Animal Production, NSAP, Michael Okpara University of Agriculture, Umudike, Nigeria, 25: 71-72.

Ahamefule, F. O., Ibeawuchi, J. A \& Nwankwo, D. I. 2005. Utilization of sun-dried fermented and ensiled cassava peal meal-based diets by weaner rabbits. Nigerian Agric. J., 36: 5258 (http://www.ajol.info/index.php/naj/article/view/3206).

Association of Official Analytical Chemist(AOAC). 2002. Official methods of analysis. AOAC, Washington DC, 1018p.

Belete Anteneh, 2006. Studies on Cattle Milk and Meat Production in Fogera Woreda: Production Systems, Constraints and Opportunities for Development, MSc thesis, Hawassa University, Hawassa, Ethiopia,154p.

Brown, S.N., Bevis, E.A \& Warriss, P.D. 1990. An estimate of the incidence of dark cutting beefintheUnited Kingdom.J. Meat Sci., 27: 249-258.

Chenost, M. 1995. Optimizing the Use of Poor Quality Roughage through Treatments and Supplementationin Warm Climate Countries with Particular Emphasis on Urea Treatment.FirstElectronicConferenceon Tropical Feeds with Particular Emphasis on Urea Treatment. FAO, Rome, pp.71-92.

Davilla, R. J., Avendano, R, L., Macias, C.., Torrentera, O. G., Zamorano, G. L., Pena, R. A \& Gonzalez, R. H. 2013. Effects of zilpaterol hydrochloride and soybean oil supplementation on physicochemical and sensory characteristics of meat from hair lamb. Small ruminant res., 114(2-3): 253-257 (http://dx.doi.org/10.1016/j.smallrumres.2013.07.009).

Dhangar, M.R., Patel, J.M \& Sanghani, T.K., 1992.Meat production potential of Indian goats. Indian J. Anim. Prod. Mgmt., 8(1\&2): 62-73.

Dien, D. L., Pathak, N. N \& Sharma, M. C. 1990. Response and carcass characteristics of male Murrah buffalo calves fed ration with different concentrate to roughage ratio. Indian Journal of Animal Nutrition, 7(4): 287-290.

Dolberg, F \& Finlayson, P. 1995. Treated straw for beef production in China. Wild Anim. Rev., 82: $14-24$.

Fajemisin, A.N, Chineke, C.M, Fadiyimu, A.A, Fajemisin, A.J \& Alokan, J.A. 2012. Dietary effects of ensiled corncobs treated with or without water, lye and urea on performance characteristics of West African Dwarf sheep. Proceedings of 17th Annual 
Conference,Animal Science Association of Nigeria (ASAN) held at International Conference Centre, Opposite Radio House, Area 8, Abuja, ( FCT), Nigeria, pp 575- 578.

Fasea, O. A., Adegoke., H. B., Ogunmekan, K. O \& Adeu, I. F. 2007. Improving feed utilization of cassavapeels. Nig. J. Anim. Prod., 34(2): 251-257.

FAO. 1993. Tropical Feeds by B. Göhl. Computerized version 4.0 edited by A. Speedy, Rome, Italy.

Gopalan, C., Sastry, B.V.R \& Balasubramanyam, S.C. 1980. Nutritive value of Indian food. National Institute of Nutrition. ICMR, India, 203p.

Hassan, W. A \& Idriss, A. 2002.A rapid assessment for dressing out percentage for Red Sokoto goats. Proceeding of the annual Conference of Animal Science Association of Nigeria, ASAN, IART, OAU, Ibadan, Nigeria, 7: 265-266.

Kadim, I. T., Mahgoub, O., Al-Ajmi, D. S., Al-Maqbaly, R. S., AL-Saqri, N. M \& Ritchie, A. 2003. An evaluation of the growth, carcass and meat quality characteristics of Omani goat breeds. Meatsci., 66: 203-210.

McDonald, P. Edwards, R.A \& Greenhalgh, J.F., 1995. Animal Nutrition. $5^{\text {th }}$ edition, Longman Group (UK) Ltd, Essex, UK, 607p.

Nsahlai, I.V., M.L.K. Bonsi, N.N. Umunna, Z. Sileshi \& Bediye, S.1998. Feed utilization strategiesforimproved ruminant production in the arid region. Ann. Arid Zone, 37: 283310.

Odeyinka, S.M. 2001. Effects of feeding varying levels of Leuceanaleucocephala and gliricidiasepium on the performance of West Africa Dwarf Goats. Nigeria J. Anm. Prod., 28: 61-64.

Olofintoye, O. O \& Salami, A. W. 2011. Development and assessment of quintic polynomial model for the prediction of daily rainfall in Ilorin, Nigeria, NSE. Technical publication of the Nigeria Society of Engineers, 46(2): 81-91.

Oosting, S.J. 1993. Wheat straw as ruminant feed, Effect of supplementation and ammonia treatmentonvoluntary feed intake and nutrient availability. $\mathrm{PhD}$ thesis, Agricultural Univ. of Wageningen, The Netherlands, 232p (www.researchgate.net/publication/40183497).

Payne, W.J.A \& Wilson, R.T. 1999. An Introduction to Animal Husbandry in the Tropics. $5^{\text {th }}$ edition, ISBN: 9780632041930, Blackwell Science Ltd, 815p. 
Preston, T. R \& Leng, R. A. 1987. Matching ruminant production system with available resources in the tropics and sub-tropics. ISBN0958829012, Penambul Books, 245p.

Schneider, R. M., Harrison, J.H \& Lorey, K.A. 1995. The effect of bacteria inoculants, beet pulp and propionic acid on ensiled wet brewers grain. Journal of Dairy Science, 78: 1096.

Steel R. G. D \& Torrie, J. H. 1980. Principles and procedures of Statistics. Biometric Approach. $2^{\text {nd }}$ edition, ISBN: 0958829012, McGraw Hill Company Inc., 252p.

Sundstol, F \& Coxworth, E. M. 1984. Ammonia treatment. In: Straw and other fibrous byproducts as feed. In: F.Sundstol and E. Owen (eds.) Elsevier, Amsterdam, Oxford, New York, Tokyo, pp196-247.

Van Soest, J.P. 1994. Nutritional ecology of the ruminant. $2^{\text {nd }}$ edition, ISBN: 080142772X, Cornell University Press, Ithaca, New York, USA, pp425-457.

Varnam, A.H \& Sutherland, J.P. 1995. The Meat and meat products-technology, chemistry and microbiology. ISBN: 978-0-412-49560-1, Springer, 26p.

Vidya, S.M., Krishna, V., Manjunatha, B.K \& Pradeepa. 2012. Micropropagation of ClerodendrumserratumL. Through direct and indirect organogenesis. Plant Tissue Cult. Biotechnol., 22: 179-185.

Yilkal, T \& Negassie, A. 2015. Urea as a Non-Protein Nitrogen Sources For Ruminants: Review. Advances in Life Science and Technology, 29: 100-105. 